\title{
Training Method and Excellent Character of Athletes Towards Basic Skills of Tarung Derajat
}

\author{
Alnedral $^{1 *}$, Syahrial Bakhtiar ${ }^{1}$, Umar $^{1}$ \\ ${ }^{1}$ Faculty of Sport Science, Universitas Negeri Padang, Indonesia \\ ${ }^{*}$ Corresponding author.Email: alnedral.fikunp@yahoo.co.id, syal_fik@yahoo.com,umar_kepel@yahoo.co.id
}

\begin{abstract}
This study aims to see the effect of training method and attitudes on basic engineering skills. This an experimental design involving 30 athletes. The samples are collected by Stratified-cluster random sampling technique. The instrument consists of basic engineering skills tests and fighting ablityof tarung derajat athetes. Data were analyzed by using technique analysis of two ways variance (ANOVA). The results of the study provide an illustration, that (1) Improvement basic athlete's technical skills are the overall level it is better to use the game sequence method, as well as on group of high-intelligent characters, while in the clevercharacter group low both method (series of games and series of training), (2) implementation of circuit training method and intelligent characters provide an interaction towards improvement basic athletes technical skills, (3) There are significant differences, between the circuit play method are more effective for highintelligent characters and low, (4) while the exercise circuit method can only be used for low-intelligent characters.
\end{abstract}

\section{Keywords: Circuit Playing Method, Tarung Derajat, Excellent-Character Athletes}

\section{INTRODUCTION}

Tarung Derajat martial art is one of the sports that is just being held for the 2nd time in Southeast Asian Games in Malaysia and September 2016 finished following PON of XX in West Java. To create an accomplished fighter, the Executive Board of the Tarung Derajat Sports Family ( $P B$ $K O D R A T)$ that annually holds various championship events, ranging from Regional Championships, national Championships, Inter-Training Units Championships, Intercultural Championships, National Presidential Cups, and Southeast Asian Games.

Tarung Derajat Martial art is declared in Indonesia, in Bandung July 18, 1972 by its creator, a son of the nation, which is Guru Haji Achmad Dradjat whose nickname $A A$ Boxer. "AA Boxer's nickname is applied and attached to Achmad Dradjat, after he is able and successful to use and apply his martial arts in a fight, where the players need and must fight in order to survive, uphold the honor and defend humanity in everyday life in harmony with the nature of his life. So, the existence of Tarung Derajat itself is identic with G.H. Achmad Dradjat's struggle, or also known as AA Boxer and now get the title "The Master of Tarung Derajat" “ [1].

Tarung Derajat has a distinctive fight that is Full Body Contact fight or free fighting, and requires a strong mentality to face the opponent both in the game arena and outside the arena and uses punches, as well as kicks for self-defense. The most important thing must be mastered by the fighters is fighting basic technique skills. To produce a great fighter must certainly be supported with adequate skills especially the mastery of good basic technique skills. Basic technique skills are one of the most important factors for a fighter. Without good basic technique skills then obviously a fighter will not have a good achievement.

"Technique is one of achievement components in sport that is the characteristics of sport itself; therefore it must be prepared as well as possible"[2]. "basic technique is the main factor besides the physical, tactical, and mental conditions of a player" [3]. Basic technique is one of the most important components and must be trained, because without it when fighting the fighters will be difficult to win. In Tarung Derajat martial art, basic techniques that are needed and must be mastered by the fighters are kick, punch, defend, and attack. "All of these techniques must be well trained and with the correct method if the players want to get an achievement" [4].

Besides mastering the techniques, it certainly should also be supported with excellent physical condition. Without the excellent physical condition, the mastery of techniques will not be maximal. Because physical ability is one of the basic components to get achievement in sports. To improve the physical condition to be good it takes some practice, because the better the condition or physical ability of a person the greater the chances for achievement. Vice versa, the lower the level of physical conditions the more difficult to get achievement.

In Tarung Derajat, physical conditions and techniques are aspects that can not be separated and must be mastered 
by every fighter. With a good physical condition without balanced with good basic techniques, it is difficult to create a good fighter as well. Therefore, the basic techniques in Tarung Derajat need to be well trained with the correct method. The types of training method to train the fighters' basic technique skills are the method that has just been created by the Master of Tarung Derajat in training the fighters' basic techniques that is known as 'Sport Drajat' who trained with the circuit playing method and circuit training method of Sport Drajat.

The method of circuit playing and circuit training will be similar with the original objectives if it is made based on the training principles. "the method of playing is a process oriented training with more centralized on players, which is the basis of open skill. In playing method, the players are as the study subjects" [5]. Training process with playing method will ease the players in the process of skills development. In the learning process, the players can directly develop the basic techniques that have been taught according to the actual game environment. W.R Smith in "play activity is a learning activity of a self-adjusting child whose impulse arises directly from within each individual by using his mind and all his soul out of the environment" [6].

"The playing method is conducted in order to achieve the learning or training outcomes efficiently and effectively in an interesting situation although discussing the difficult things" [7]. Then, it is also used to build a dynamic, enthusiastic, and relaxing learning or training situation. The characteristics of the game is to create an interesting or fun and serious but relaxed learning or training situation. The game is used for creating the passive learning situation to the active one, from rigid to motion, and from saturation to joy. "selecting a series of training is crucial in improving students' achievement in every sport" [6]. In the series of training method can be performed some elements of play, such as technical exercises, either separately or in combination.

Tarung Derajat Martial Art of West Sumatra has experienced a glorious period, which always get a gold medal in every national championship that started in Bandung in 1998. The tradition to bring this gold medal is always carved by West Sumatra KODRAT fighters, and even ever get an honorable place as a sport achievement that is ever won nationally as the 2 nd General Champion at the Pre-PON of 2007 (earned three golds, one silver, three bronzes), and two West Sumatra fighters were awarded as "best fighter" (Pengprov Kodrat of West Sumatera, 2007) . In 2010 until 2015, Tarung Derajat of West Sumatera has experienced a decrease in its achievement, but the golden tradition which is always carved by the fighters can be realized again in PON XVIII-2016, where they get 2 (two) golds and 1 (one) bronze. The question is how to improve the achievement and maintain the ratings already earned.

Based on the results of observations done, this occurs because of a technical error that is often done by the fighters, that the basic techniques used are not based on the techniques allowed in the fight. Where the basic technique is divided into three phases, the initial phase is taking the start, the main phase is to do punching and kicking movement towards the allowed target (head, front body starting from waist up) and the final phase after doing the attack, the fighter is back to his original position. This is often ignored by West Sumatra fighters during training and while in the game. Because the method of training given still uses the standard method, which trains the technique without a sequence like real fighting, so the fighter is unfamiliar with the battle situation.

From this fact the trainers should pay more attention to the method used to create good techniques to the fighters. So, the fighter can better master the right basic techniques of fighting, and be able to create the fighters who can excel in the National and International arena. It is also expected to the fighters to be more serious in doing practice, in order to do the best when fighting and can get the desired achievement. To restore those golden days is not an easy matter. The trainer has a great "Homework" to get it back, the trainers have to look again at the aspects to watch out for such as training method, fighter's physical training programs, psychological aspects such as training motivation, fighting mental, emotional, intelligence level, and excellent characters of fighters

Based on the results of the preliminary study it can be concluded that the trainer, is less or no longer polite, but more hard-faced and hard to the athletes even shouting them" so the athletes tend to be brutal in matches, many of them are disqualified (Porprov XI-2014 and Porprov XII2016), the technique does not develop, like the Master' term said, tend to choose the winner from "bad to the baddest". This is indicated for the low ability of the skills values of aspects in playing, moral attitude, cooperation, life force, and the moral in doing Tarung Derajat.

"Nowadays, the pamor of Tarung Derajat martial art in West Sumatra is declining, or stagnating, whether viewed from the medals at the National event, or the moral-mental attitude of the Tarung Derajat fighters" [8]. In addition, there is also a practice that is not in accordance with the demands of mortal (moral-mental) which become the basic content of $B T D-M G$, as human being that develops independently according to a principle namely "Make yourself by yourself" with the training philosophy is "I learn and practice martial arts is to conquer myself, but not conquered by others" [1].

"The mental skills are defined like processes or techniques making it possible to control or to direct the thoughts, the strategies, the feelings and the emotions essential to the performance"[9]. It means that mental skills are defined like processes or techniques that allow to control or direct thoughts, strategies, feelings and emotions that are important for performance.

The practice of abusing the teaching ways to the BTDMG needs to be corrected and restored to its original form, which is self-sustaining, high-minded, independent self development in a healthy and strong physical condition. The organization of BTD-MG is not solely aimed at achieving medals / achievement levels, but rather at the development of the athletes' characters, which is excellent characters that more typical called the moral and mental BTD. 
The most widely recognized definition of emotional intelligence is "the ability to monitor emotions and to use the information to guide actions. It means emotional intelligence which is known well is the ability to monitor emotions and use that information to guide the action.

Following the principles of educational scholarship, excellent-characters learning / training strategies are more popular in implementing the Thinking, Being, Acting, and Responsible Strategy (abbreviated BMB3) as a standard in the training process to improve the training dynamics, improve the understanding and master the pratices in the training process. The elements of BMB3 can be regarded as a reflection of improvement in achievement that touches with human dignity in educational situation. Therefore, learning strategies to strengthen the athlete's moral-mental in the training, should also be considered, developed, and applied by trainers to athletes in the training process that further ensures the development process of excellent characters. The BMB3 elements in the training of BTD fighter is the major power in living on BMB3, improving the basic technique skills, and athletes' excellent character. The use of strategies in learning is necessary because to facilitate the learning process so as to achieve optimal results.

Based on the problems above, so the main problem that need to be considered in order to improve learning / training outcomes is the mastery of basic technique skills and mastery of the excellent character of BTD athletes by considering the BMB3 learning strategy factors that is related to the training method. In this case is the circuit of playing method and circuit training method in Tarung Derajat.

\section{METHODOLOGY}

This study is a kind of development research or Research and Developmen (R \& D). development research is a process or steps, to develop a new product or refine an existing product that can be accounted for.

The implementation of this research is done in two stages, that are; (1) development of BMB3 model or learning strategy in BTD-MG training followed by development of learning tools as completeness of application in class / unit, i.e. (a) development of learning tools relevant to the model, (b) implementation / experiment in class, with using experimental method, and (c) validation to be effectively implemented in training units. (2) after the model is validated, it is applied or conducting experimental research, that is manipulating or treating through circuit of playing method, skill of basic technique of Tarung Derajat, and mastery of the BTD-MG athletes' excellent character on training units in West Sumatera.

The development of training method on preliminary study activities includes, literature review, field survey, needs analysis and curriculum analysis in accordance with the needs of content structure analysis of GBBP Tarung Derajat training (PB Kodrat, 2003). The plan of the development of sports drajat method, with the activities of designing materials and training objectives of BTD-MG, learning approaches, BMB3 learning strategies developed (2013), learning method (being developed), learning techniques and tactics. Furthermore, making the initial product of development of sports drajat training method in Tarung Derajat (circuit of playing method). Experiencing test validation, experimenting and improving the learning method of circuit playing in gradual and sustainable way; in experimental group is using (play circuit method), it is expected that the results of the practice are better than the control group use (the circuit training method). Thus, the application through experiment (playing method) is to see the comparison of the effect on the differences of excellent character-acquisition and the improvement of athletes' basic technique skills caused by different training method (control group).

The design of experimental research to test the product of circuit playing method (experimental group) and circuit training method (control group) on the mastery of basic technique skills, and excellent characters of BTD athletes in training units of martial art in West Sumatera. Thus, the research has a pattern of "Factorial Design 2 x 2".Samples were taken by stratified-cluster random sampling, which was a sample of 30 athletes and 30 control group athletes.Data were collected by documentation studies, interviews, questionnaires (questionnaires), and athletes' basic technique skills tests.

Hypothesis test is done by analysis of variance (Anova). The reason using Anova analysis technique to test hypothesis is data in comperative form with devendent variable two-sample.

\section{RESULT AND DISCUSSION}

Based on descriptive analysis of collected data is; for the condition of basic technique skills in the group of highexcellent character, it is proved that the athletes' progress after being trained with the method of playing gains the averages of 7.75 , while the group of training method is averaged 4.44. So, progress of experimental group is higher than the control group.

For the low excellent character group, it is proved that the athletes' progress after being trained with circuit playing method is in the average of 3.69 , whereas the group of circuit training method is averaged 4.73 or a control group gets higher progress than the experimental group. For the whole without looking at the high- or lowexcellent characters, got the average for the experimental group is 5.72, whereas the control group is 4.58. Thus, low-characters athletes are taught by circuit training method, get the better progress.

The interaction between the implementation of the method with the excellent characters has an operational $\mathrm{F}$ of 27,784 . This value is greater than F table, that is 4.013 on $\alpha 0.05$. It means that the null hypothesis ( $\mathrm{H} 0)$ was rejected. Thus, the research hypothesis states that "There is an interaction of the implementation of training method used with mastery of excellent characters to increase training outcomes of Tarung Derajat athletes in training units of West Sumatra, its truth is empirically tested. 
There is the difference in basic technique skills of Tarung Derajat athletes who both possess high-excellent characters between the implementation of circuit playing method and the circuit training method in the training units of West Sumatra. The difference can be proved by the result of the calculation on the aspect of the athletes' basic technique assessment. That is the operational $\mathrm{T}$ value $=$ 1.784 is greater than Ttable $=1.673$ at alpha 0.05 , which means that there is a significant difference. From the results of the calculation shows that the mastery of basic technique skills of Tarung Derajat athletes trained by the circuit playing method (experimental group) is better than using the circuit training method (control group) in training units of West Sumatra.

There is the difference in basic technique skills of Tarung Derajat athletes who both possess low-excellent characters between the implementation of circuit playing method and the circuit training method in the training units of West Sumatra. The difference can be proved by the result of the calculation on the aspect of the athletes' basic technique assessment. That is the operational $\mathrm{T}$ value $=$ 1.784 is greater than Ttable $=1.673$ at alpha 0.05 , which means that there is a significant difference. From the results of the calculation shows that the mastery of basic technique skills of Tarung Derajat athletes trained by the circuit playing method (experimental group) is better than using the circuit training method (control group) in training units of West Sumatra.

There is a difference in mastery of basic technique skills of Tarung Derajat athletes as a whole using the circuit playing method compared with the circuit training method. To know the difference of training result of Tarung Derajat athletes in training units of West Sumatera, the researcher used statistical approach "Anova" with the result is F-operational analysis $=7,556$, while F-Table $=$ 4,013. This means that there is significant difference between the two strategies used.

\section{CONCLUSION}

The improvement of basic technique skills of Tarung Derajat athletes is better using the circuit training method, as well as in the high-excellent characters group, whereas in the low-excellent characters group both method (circuit playing and circuit training) provide the improvement. There is a correlation of the implementation of the circuit playing method with the mastery of the excellent character to increase the training outcomes of Tarung Derajat athletes in training units of West Sumatra. It means that the implementation of the circuit playing method is more suitable for high-and low-excellent character athletes, while the circuit training method is only suitable for lowexcellent character athletes.

There is the difference of basic technique skills of Tarung Derajat athletes that have high-excellent character between the implementation of circuit playing method compared with the circuit training method in the training units of West Sumatra. It means that the implementation of circuit playing method is more effective than the circuit training method in improving the result of basic technique skills by considering the high-excellent character of Tarung Derajat athletes. There is the difference of basic technique skills of Tarung Derajat athletes that have lowexcellent character between the implementation of circuit playing method compared with the learning strategy of circuit training method in the training units of West Sumatera. It means that the circuit playing method is more effective than the circuit training method in improving the results of basic technique skills by considering the lowexcellent character of the athletes.

\section{REFERENCES}

[1] Chairad, Muhammad. "Sejarah dan Perkembangan Beladiri Tarung Derajat. Jurnal Ilmu Keolahragaan”. Vol. 13(2). pp 29-37, 2014.

[2] Syafruddin. "Ilmu Kepelatihan Olahraga, Teori dan Aplikasinya Dalam Pembinaan Olahraga". Padang: UNP Press. 2011, pp 22.

[3] Iskandar dan Yulianingsih. "Peningkatan Keterampilan Passing Atas dalam Permainan Bolavoli Melalui Metode Bermain Siswa Kelas VIII SMP Negeri 3 Sungai Ambawang Kabupaten Kubu Raya". Jurnal Pendidikan Olahraga. 4 (2), pp 157 $169,2015$.

[4] Alnedral. "Strategi Pembelajaran PJOK". Yogyakarta: Penerbit Andi. 2015, pp 17.

[5] K. Budiyono. "Perbedaan Pengaruh ModelLatihanBermainDan DrillTerhadap Kemampuan SepakSila Dalam Permainan SepakTakraw Pada Atlet PutriUkm UtpSurakarta Tahun 2015. JurnalIlmiah Spirit, Vol. 15 No.3, pp 1411-8319. 2015.

[6] Gusril. "Perkembangan Motorik Pada Masa AnakAnak”. Padang: UNP Press. 2015, pp 46.

[7] Alnedral. "The Effects of BMB3 Learning Strategies on Tarung Derajat Training Outcome". Proceeding Seminar Internasional Pendidikan Serantau ke-6 UKM-UR. Pp. 2753-2767. 22-23 Mei 2013.

[8] Alnedral. "Efektivitas Strategi Pembelajaran BMB3 dan Karakter-Cerdas Terhadap Keterampilan Teknik Dasar Beladiri Tarung Derajat". Prosiding KONASPI VIII 2016, UNJ Jakarta. Pp. 44-55. 1215 Oktober 2016.

[9] A. Fairouz. "Evaluation of the Mental Skills of the High Level Athletes: Example of the Athletes of Martial Arts". IOSR Journal Of Humanities And Social Science (IOSR-JHSS) Volume 10, Issue 4). pp 58-65 (May. - Jun. 2013). 